\title{
SELF-MANAGEMENT DAN DUKUNGAN KELUARGA PADA LANJUT USIA DENGAN PENYAKIT KRONIS
}

\author{
Nurul Fatimah ${ }^{1}$, Ani Auli Ilmi ${ }^{1}$, Patima ${ }^{1}$ \\ ${ }^{\mathbf{1}}$ Fakultas Kedokteran dan Ilmu Kesehatan UIN Alauddin Makassar \\ Email : ani.auli@uin-alauddin.ac.id
}

\begin{abstract}
Chronic illness is a long-term health disorder and cannot be cured without definitive treatment, requires lifelong support and care. In the elderly there is a decline in cells due to the aging process which can cause various diseases including chronic diseases. Chronic illness Not only causes pain, death, and physical disability of sufferers, but also a long treatment procedure can cause sufferers to experience psychological stress and feel hopeless. So that good family support is needed which can further improve good self-management in patients. Therefore, the authors are interested in conducting a literature study to determine the effect of self-management and family support on age and chronic illness. This type of writing is a literature review using Google Scholar and Garuda Portal. Then after the identification, screening and feasibility process, there are 4 national literature, 2 international literature and 1 text book that fits the inclusion criteria. Based on the results of the seventh literature, it can be concluded that there is a positive influence on self-management and family support on the handling of the elderly with chronic diseases. Both are interconnected, clients with chronic diseases can trust and use self-management well when they get support from a good family. Therefore elderly people with chronic diseases and families are expected to be able to apply this to be one of the actions in dealing with chronic diseases.
\end{abstract}

Keywords: Self-management, family support, elderly, chronic disease

\section{PENDAhuluan}

Penyakit kronis didefinisikan oleh World Health Organization (WHO) sebagai durasi panjang yang umumnya lambat dalam perkembangan dan tidak ditularkan dari orang ke orang (WHO, 2014). Penyakit kronis dikenal sebagai gangguan kesehatan jangka panjang dan tidak dapat disembuhkan tanpa pengobatan definitif, membutuhkan dukungan dan perawatan seumur hidup (Thompson J., 2009). Penyakit kronis merupakan salah satu beban ganda dalam bidang kesehatan selain penyakit infeksi yang merajalela. Penyakit tidak menular diprediksikan akan mencapai $73 \%$ pada tahun 2020 dan menjadi penyebab kematian terbesar. WHO menyatakan pula bahwa $60 \%$ dari beban penyakit dunia adalah hipertensi (WHO, 2008).

Penyakit kronis terbanyak pada pria dan wanita yang berusia 50-74 tahun di Amerika
Serikat, Inggris, dan Eropa adalah hipertensi, kerusakan mobilitas, penyakit jantung, diabetes dan penyakit paru (American Journal of Public Health, 2009). Kementerian Kesehatan dalam Riset kesehatan dasar ([riskesdas] 2013) menyatakan bahwa terdapat lima penyakit yang paling banyak menyerang lansia di Indonesia yaitu hipertensi, radang sendi, stroke, penyakit paru obstruktif kronis (PPOK), dan diabetes melitus.

Lanjut usia merupakan kelompok manusia yang memasuki tahap akhir kehidupannya. Pada kelompok lanjut usia ini terjadi proses penuaan yaitu suatu proses yang ditandai dengan gagalnya mempertahankan keseimbangan terhadap kondisi stres fisiologis. Kegagalan yang sering didapat berupa menurunnya kemampuan hidup serta meningkatnya kepekaan individu (Turana, dkk 2013). Menurut pasal 1 ayat (2), (3), (4), UU N0.13 tahun 1998 tentang kesehatan 
dikatakan bahwa lanjut usia adalah seseorang yang telah mencapai usia 60 tahun (Maryam, 2008).

Pada lanjut usia terjadi kemunduran sel-sel karena proses penuaan yang dapat menimbulkan berbagai macam penyakit termasuk penyakit-penyakit kronis. Penuaan adalah suatu karakteristik dari proses fisiologis dan mengalami perbedaan yang irreversible pada fungsi fisiologis lansia. Hal tersebut akan berdampak pada berbagai aspek kesehatan. Proses menua menimbulkan suatu proses hilangnya kemampuan jaringan secara perlahan-lahan dalam memperbaiki diri atau mengganti dan mempertahankan fungsi normalnya sehingga tidak mampu bertahan terhadap infeksi serta memperbaiki kerusakan yang diderita (Maryam, 2008), sebagaimana firman Allah dalam QS. Ar-Rum/30:54

Terjemahnya :

"Allah, dialah yang menciptakan kamu dari keadaan lemah, Kemudian dia menjadikan (kamu) sesudah keadaan lemah itu menjadi kuat, Kemudian dia menjadikan (kamu) sesudah Kuat itu lemah (kembali) dan beruban. dia menciptakan apa yang dikehendaki-Nya dan dialah yang Maha mengetahui lagi Maha Kuasa” (Kementrian Agama RI, 2014).

Ayat ini mengingatkan (manusia) akan fasefase yang telah dilaluinya dalam penciptaannya, dari suatu keadaan kepada keadaan yang lain. Asal mulanya manusia itu berasal dari tanah liat, kemudian dari air mani, kemudian menjadi segumpal daging, kemudian menjadi tulang yang dilapisi dengan daging, lalu ditiupkan roh ke dalam tubuhnya. Setelah itu ia dilahirkan dari perut ibunya dalam keadaan lemah, kecil, dan tidak berkekuatan. Kemudian, manusia mengalami perkembangan secara bertahap; dari bayi menjadi kanak-kanak, lalu menjadi remaja atau masa muda, kemudian memasuki masa dewasa. Sejalan dengan perkembangan ini, kemampuan fisik dan rohani manusia- pun berkembang. Inilah yang dimaksud dengan keadaan kuat sesudah lemah. Lama kelamaan, kekuatan pada diri manusia itu berangsur menghilang. Otot-otot yang tadinya kekar mulai melemah, jarak pandang mulai terbatas, pendengaran sudah tak nyaring lagi, gigi yang rapi satu persatu mulai rontok. Kemudian mulailah berkurang dan menua, lalu menjadi manusia yang lanjut usia dan memasuki usia pikun; dan inilah yang dimaksud keadaan lemah sesudah kuat. (Shihab, Q., 2002).

Penyakit kronis tidak hanya mengakibatkan kesakitan, kematian, dan ketidakmampuan fisik dari penderita, namun juga prosedur pengobatan yang panjang dan menghabiskan banyak biaya. Oleh karena itu, sisem pelayanan kesehatan pada klien dengan penyakit kronis berubah dengan memperpendek masa rawat inap di Rumah Sakit dan beralih pada program perawatan di rumah (Denham \& Looman, 2010).

Self-management adalah suatu proses di mana klien mengarahkan sendiri perubahan tingkah lakunya dengan strategi terapeutik. Berdasarkan Theory of Planned Behavior (TPB) diharapkan perilaku terbentuk karena ada niat (intention) yang ditentukan oleh sikap, norma subjektif dan persepsi individu. Pemberian self-management program yang berisi edukasi pengelolaan penyakit kronis diharapkan dapat membangun persepsi positif melalui learning process, sehingga menghasilkan pemahaman untuk mengubah tingkat awareness pasien terhadap kesehatan dengan perubahan sikap dan norma subyektif klien dengan penyakit kronik, maka selanjutnya akan terbentuk perilaku sehat yaitu kepatuhan berobat diharapkan menghasilkan peningkatan koping dan didukung dengan niat berprilaku sehat tinggi.

Peran dan fungsi keluarga dalam teori sistem salah satunya adalah sebagai pemberi perawatan (caregiver) pada anggota 
keluarga yang sakit. Konsep normalisasi pada keluarga yang memiliki anggota keluarga dengan penyakit kronis dilakukan dengan merubah gaya hidup yang mendukung proses pengobatan. Keluarga yang mendapatkan dukungan dari lingkungan sosial keluarganya mengalami tingkat stress yang lebih rendah daripada yang tidak mendapatkan dukungan sosial oleh keluarga. Hal ini menggambarkan bahwa pentingnya peran perawat sebagai konselor untuk mengarahkan keluarga dalam menggunakan strategi koping yang positif (Allender, Rector, \& Warner, 2010).

Selanjutnya peneliti tertarik melakukan studi literatur baik dari jurnal-jurnal penelitian nasional maupun dari jurnal-jurnal penelitian internasional untuk melihat bagaimana self-management dan dukungan keluarga berpengaruh pada lanjut usia dengan penyakit kronis.

\section{METODE}

Jenis tulisan bersifat studi literatur yang disajikan secara deskriptif. Data yang digunakan penulis diperoleh dari beberapa literatur jurna, text book, dan penelitian yang telah dilakukan yang berkaitan dengan karya tulis ini baik yang bersumber dari literature nasional maupun internasional. Dalam memilih jurnal yang akan dianalisis, penulis melihat dengan berbagai kriteria yaitu :

2.1 Kriteria Inklusi :

a. Literatur jurnal tahun 2015-2018

b. Literatur text book 2013-2018.

c. Literatur full text yang membahas tentang self-management, dukungan keluarga, lanjut usia, dan penyakit kronis (diabetes mellitus, stroke, penyakit jantung koroner (PJK), hipertensi).

d. Literatur dengan sistematik penulisan yang baik seingga penulis bisa mendapatkan gambaran secara jelas.

\subsection{Kriteria Ekslusi :}
a. Literatur jurnal di bawah 2015.
b. Literatur text book di bawah 2013.
c. Literatur yang tidak jelas sumbernya

\section{HASIL}

Dari hasil pencarian artikel penelitian, penulis menemukan empat jurnal nasional, 2 jurnal internasional, dan 1 text book yang membahas tentang self-management dan dukungan keluarga terhadap penyakit kronis dengan penyakit yang berbeda-beda.

Sumber utama penelitian ini adalah jurnal yang ditulis oleh Indah Galuh Lestari, dkk. (2018), yaitu dengan judul "Pengaruh SelfManagement Terhadap Tekanan Darah Lansia yang Mengalami Hipertensi". Dari hasil mereview jurnal tersebut didapatkan kesimpulan bahwa terdapat pengaruh postif yang sangat signifikan antara selfmanagement dengan tekanan darah (sistolik dan diastolik) pada lansia yang mengalami hipertensi di Posbindu Dukuhturi-Bumiayu. Hasil yang didapat berdasarkan uji Spearman Rank dari self-management dengan tekanan darah sistolik didapatkan $p$ value $=0,000(<0,05)$ dan hasil dari selfmanagement dengan tekanan darah diastolik didapatkan $p$ value $=0,034 \quad(<0,05)$. Penelitian ini membuktikan bahwa ada pengaruh yang sangat signifikan antara selfmanagement dengan tekanan darah baik sistolik maupun diastolik. Semakin tinggi self-management maka akan semakin rendah tekanan darah lanjut usia yang mengalami hipertensi. Sebaliknya, semakin rendah selfmanagement maka akan semakin tinggi tekanan darah lanjut usia yang mengalami hipertensi. Hal tersebut berpengaruh karena self-management merupakan serangkaian teknis untuk mengubah atau mengontrol perilaku, pikiran, dan perasaan seseorang. Self-management merupakan suatu strategi kognitif behavioural yang bertujuan untuk membantu klien agar dapat mengubah perilaku negatifnya dan mengembangkan perilaku positifnya dengan jalan mengamati 
diri sendiri. Hipertensi merupakan penyakit kronis, oleh karena itu pasien harus bertanggungjawab dalam melakukan pengelolaan diri sendiri (self-management) baik untuk menurunkan gejala maupun menurunkan resiko komplikasi.

Jurnal kedua ditulis oleh Hannah L., Parke, dkk. (2015) from Institute of Medical Informatics and Population Health Sciences, Department of Primary Health Sciences, University of Oxford, Oxford, United Kingdom. Dengan judul "Self-Management Support Interventions For Stroke Survivor: A Systematic Meta-Review”. Hasil dari jurnal ini ditemukan bahwa terminologi manajemen diri masih jarang digunakan dalam konteks stroke. Meskipun istilah manajemen diri jarang digunakan, ekemenelemen kunci dari dukungan manajemen diri seperti penetapan tujuan, perencanaan tindakan, dan pemecahan masalah adalah komponen inti dari intervensi rehabilitasi terapi. Para penulis menemukan hasil yang berkualitas tinggi yang mendukung manajemen diri dalam konteks rehabilitasi terapi yang diberikan segera setelah kejadian stroke menghasilkan perbaikan jangka pendek ( $<1$ tahun) dalam aktivitas dasar dan diperpanjang dari kehidupan sehari-hari dan penurunan hasil yang buruk (ketergantunga/kematian). Self-management mengacu pada kemampuan individu untuk mengelola gejala, perawatan, perubahan fisik, psikososial, dan gaya hidup yang melekat pada hidup dengan kondisi kronis. Program self-management berusaha untuk memberdayakan individu untuk mengatasi penyakit dan menjalani kehidupan yang berkualitas yang lebih baik dengan lebih sedikit pembatasan dari penyakit mereka dengan mengembangkan self-efficacy, yang merupakan tingkat kepercayaan yang dimiliki seseorang dalam kemampuannya untuk berhasil dalam me-manage diri mereka yang memiliki penyakit kronis. Penting untuk dicatat perbedaan antara inisiatif untuk membangun manajemen diri pasien dan dukungan manajemen diri. Dukungan manajemen diri memerlukan penyedia atau tim perawatan kesehatan untuk melakukan serangkaian tugas tertentu untuk menciptakan efikasi diri yang diperlukan bagi pasien untuk menangani secara yakin dengan berbagai gejala emosional, fisik, dan fisiologis mereka sendiri dari penyakit kronis mereka. Dari semua elemen CCM (Chronic Care Management), manajemen diri telah terbukti menjadi yang paling efektif dalam meningkatkan hasil di berbagai macam penyakit dan populasi di mana ia telah dipelajari/diteliti (Johnston, S., dkk., 2010).

Jurnal penelitan ketiga ditulis oleh Damayanti Siska, dkk. (2015) yang berjudul "Dukungan Keluarga pada Pasien Diabetes Melitus Tipe 2 dalam Menjalankan SelfManagement Diabetes". Setelah mereview jurnal ini didapatkan hasil bahwa lebih dari setengah responden $(55,1 \%)$ melaporkan dukungan keluarga favorable. Dilihat dari dimensi dukungan keluarga, setengah responden $(50 \%)$ melaporkan dukungan keluarga favorable pada dimensi emosional dan setengahnya lagi melaporkan unfavorable $(50 \%)$, dimensi penghargaan $57,69 \%$ melaporkan favorable dan $42,31 \%$ melaporkan unfavorable, dimensi dukungan informasi 57,69\% melaporkan favorable dan $42,31 \%$ melaporkan unfavorable, dimensi dukungan instrumental $55,12 \%$ melaporkan favorable dan $44,87 \%$ melaporkan unfavorable. Namun berbeda dengan dimensi dukungan yang lain, dimensi dukungan lingkungan sosial lebih dari setengah responden $(51,28 \%)$ melaporkan unfavorable dan $48,71 \%$ melaporkan favorable. Penelitian ini membuktikan bahwa dukungan keluarga terhadap anggota keluarga yang memiliki penyakit DM tipe 2 berada pada kategori favorable yaitu mendukung, dimana dukungan keluarga tersebut selanjutnya berdampak pada selfmanagement penderita DM tipe 2 dalam mengontrol dan mengatur penyakit mereka 
secara mandiri. Namun masih terdapat dimensi keluarga yang berada pada kategori unfavorable yaitu dimensi dukungan lingkungan sosial. Sikap unfavorable tersebut dikarenakan pemberian dukungan keluarga pada aspek jaringan tidak menjadi fokus keluarga di Indonesia sebagai salah satu cara dalam melakukan perawatan diabetes, sehingga kegiatan-kegiatan sosial yang berkaitan dengan perawatan diabetes cenderung diabaikan karena keluarga lebih mempercayai penatalaksanaan yang berkaitan dengan medis (Damayanti, 2015).

\section{PEMBAHASAN}

Dukungan keluarga adalah dukungan yang diartikan sebagai perasaan memiliki serta perasaan saling terkait dan terikat dengan orang lain serta lingkungannya yang bisa menimbulkan kekuatan yang dapat membantu menurunkan perasaan terisolasi yang biasanya dirasakan oleh penderita. Salah satu karakteristik budaya orang Indoneisa yakni selalu membutuhkan dukungan orang lain, terlebih ketika mereka mengalami sakit. Karakteristik masyarakat Indonesia yang memiliki ikatan kekeluargaan yang erat dan akrab membuat sumber dukungan keluarga akan mudah diperoleh oleh anggota keluarga yang memiliki penyakit kronis. Adapun kekerabatan keluarga yang erat di Indonesia dibuktikan dengan adanya kebiasaan salah satu anggota keluarganya menemani anggota keluarganya yang dirawat di rumah sakit. Berbeda dengan kekerabatan keluarga di Negara Barat yang menyerahkan sepenuhnya perawatan anggota keluarganya yang sakit kepada petugas kesehatan, dalam hal ini perawat (Sudiharto, 2008).

Literatur keempat yang penulis review berasal dari Text Book yang berjudul "SelfManagement Support for Canadians With Chronic Health Condition - A Focus for Primary Health Care" yang ditulis oleh Health Council of Canada (2013). Sekitar separuh dari seluruh warga Kanada hidup dengan setidaknya satu kondisi kesehatan kronis, dan lebih dari satu dari empat orang Kanada melaporkan memiliki dua atau lebih kondisi kronis. Banyak yang akan hidup dengan baik dan panjang meskipun memiliki masalah kesehatan jangka panjang, tetapi yang lain tidak. Dan literatur ini adalah tentang bagaimana kita dapat memastikan kualitas hidup yang lebih baik untuk semua dengan self-management. Setelah melakukan tinjauan pada buku teks ini, penulis menyimpulkan bahwa banyak pasien dengan kondisi kronis akan membutuhkan pendidikan pasien dan dukungan selfmanagement. Penelitian dengan pasien diabetes telah menunjukkan bahwa menambah program pendidikan pasien tradisional dengan elemen tambahan dukungan manajemen diri dapat meningkatkan hasil kesehatan (McGowan, 2011). Pasien yang dapat mengelola dirinya sendiri telah mengurangi efek yang berhubungan dengan penyakit dan dapat mengubah penggunaan layanan kesehatan mereka karena mereka memantau gejala mereka dan tahu bagaimana mencegah dan menanggapi masalah-masalah yang berhubungan dengan kesehatan mereka. Apa yang membantu pasien untuk berhasil mengelola diri sendiri siap untuk berubah, percaya diri dalam kemampuan mereka untuk mengelola diri sendiri, melek kesehatan, didukung oleh penyedia perawatan kesehatan utama, dan tidak kalah penting didukung oleh keluarga, teman, atau teman sebaya. Jadi apa yang membuat selfmanagement yang baik? Self-management yang baik adalah pasien yang secara aktif terlibat dalam perawatan mereka dan mampu membuat keputusan yang mendukung kesehatan mereka, termasuk mengetahui kapan mereka dapat mengelola sendiri dan kapan harus mencari bantuan profesional. Self-management yang baik adalah orang yang: 1) memiliki pengetahuan tentang kondisi mereka dan tentang hal-hal yang dapat mereka lakukan untuk meningkatkan peluang mereka memiliki kualitas hidup 
yang baik, 2) termotivasi untuk mengelola sendiri, menggunakan informasi dan dukungan terstruktur, 3) mengikuti rencana perawatan pribadi, yang dikembangkan dalam kemitraan aktif dengan penyedia layanan kesehatan mereka, termasuk tujuan untuk perawatan mereka dan rencana tindakan khusus yang dapat mereka lakukan di rumah, 4) aktif berbagi dalam pengambilan keputusan dengan penyedia layanan kesehatan mereka, 5) memantau dan mengelola gejala-gejala kondisi mereka di antara kunjungan perawatan kesehatan, 6) mengetahui bagaimana memecahkan masalah atau mencari bantuan untuk mengelola dampak kondisi pada kehidupan fisik, emosional, keluarga, dan sosial mereka, 7) mengadopsi gaya hidup yang meningkatkan kesehatan, dan 8) memiliki akses ke layanan dukungan dan kemampuan untuk menggunakannya. Dengan dukungan yang tepat, idealnya semua orang dengan kondisi kronis bisa menjadi manajer diri yang baik. Tetapi sejumlah faktor pribadi dan dukungan keluarga dapat membuat lebih mudah atau lebih sulit bagi orang untuk mendapatkan manfaat dari dukungan selfmanagement (de Silva, D. 2011).

Jurnal penelitian kelima ditulis oleh Isra, M. dkk., (2017) yang berjudul "Hubungan Dukungan Keluarga Dengan Derajat Hipertensi Pada Pasien Hipertensi di Puskesmas Ranomuut Kota Manado". Setelah penulis mereview jurnal ini didapatkan hasil bahwa jumlah responden yang memiliki dukungan keluarga tinggi sebanyak 39 responden $(57,4 \%)$ dari 68 total responden, yang berada pada klasifikasi pre hipertensi sebanyak 37 responden $(54,4 \%)$, dan yang berada pada klasifikasi hipertensi sebanyak 31 responden $(45,6 \%)$, dan didapatkan nilai $\mathrm{p}=0,000$. Sehingga dapat ditarik kesimpulan bahwa ada hubungan dukungan keluarga dengan derajat hipertensi. Keluarga menjadi support system dalam kehidupan pasien hipertensi, agar keadaan yang dialami tidak semakin memburuk dan terhindar dari komplikasi akibat hipertensi. Jadi dukungan keluarga diperlukan oleh pasien hipertensi yang membutuhkan perawatan dengan waktu yang lama dan terus-menerus (Ningrum, 2012). Penelitian ini membuktikan bahwa terdapat perbedaan yang signifikan antara responden yang memiliki dukungan keluarga yang tinggi dan responden yang memiliki dukungan keluarga yang rendah. Responden dengan dukungan keluarga yang tinggi cenderung memiliki derajat hipertensi yang rendah, sedangkan responden dengan dukungan keluarga yang rendah cenderung memiliki derajat hipertensi yang tinggi. Keluarga dapat membantu pasien hipertensi antara lain dalam mengatur pola makan yang sehat, mengajak olahraga bersama, menemani dan mengingatkan untuk rutin dalam memeriksa tekanan darah.

Friedman (2010), mengemukakan bahwa keluarga adalah sumber utama konsep sehat sakit dan perilaku sehat. Penelitian di bidang kesehatan keluarga secara jelas menunjukkan bahwa keluarga sangat berpengaruh besar terhadap kesehatan fisik anggota keluarga, dan sebaliknya disfungsi keluarga dapat menyebabkan pasien tidak efektif menjalani terapi, pola makan yang buruk yang pada akhirnya akan memperparah kondisi pasien. Sehingga dapat ditarik kesimpulan bahwa salah satu hubungan sebab akibat antara keluarga dengan penyakit yaitu dukungan keluarga.

Jurnal keenam dari Journal of School Nursing yang ditulis oleh Huana Carolina C., dkk., (2015) dengan judul "Strategies for Self-Management Support By Patients With Stroke: Integrative Review". Setelah melakukan tinjauan jurnal, penulis menyimpulkan bahwa jurnal ini bertujuan untuk menganalisis strategi dukungan selfmanagement oleh pasien dengan stroke dalam metodologi dari lima A (ask, advice, assess, assist and arrange) yaitu meminta, nasihat, menilai, membantu dan mengatur. 
Hasil dari penelitian ini adalah penggunaan lima strategi A memberikan pedoman untuk manajemen yang lebih baik dari pasien dengan stroke dengan biaya yang lebih rendah dan efektivitas yang lebih tinggi. Pasien stroke memiliki kebutuhan khusus karena mereka adalah subyek yang membutuhkan perawatan yang berbeda. Karena ini adalah penyakit yang tiba-tiba muncul, mereka membutuhkan perawatan profesional yang lebih besar di saat-saat pertama, diikuti oleh tanggung jawab yang lebih besar oleh individu untuk perawatan mereka sendiri. Dukungan self-management yang terstruktur sesuai dengan strategi 5A memberikan pedoman untuk pendekatan yang lebih baik untuk pasien dengan stroke, dengan biaya yang lebih rendah dan efektivitas yang lebih besar. Terutama ketika digunakan rehabilitasi fisik dan sosial individu. Oleh karena itu, penting untuk mengembangkan rencana individual manajemen diri dengan tujuan realistis yang memenuhi kebutuhan pasien stroke. Ini harus disusun bersama dengan pasien dan anggota keluarga, serta semua sumber yang tersedia di masyarakat harus terdaftar untuk kinerja efektifnya (Lorig KR., Dkk., 2008).

Jurnal penelitian ketujuh ditulis oleh Mufarokhah, H., dkk. (2016) yang berjudul "Self-Management Program Meningkatkan Koping, Niat dan Kepatuhan Berobat Pasien Penyakit Jantung Koroner (PJK)". Setelah penulis mereview jurnal ini didapatkan hasil bahwa: 1) program manajemen diri meningkatkan tingkat koping pada pasien dengan PJK $(0,001), 2)$ program manajemen diri meningkatkan tingkat niat pada pasien dengan PJK $(0,001), 3)$ program manajemen diri meningkatkan tingkat kepatuhan pengobatan pada pasien dengan PJK $(\mathrm{p}=0,001)$. Berdasarkan teori planned behavior dapat dijelaskan proses yang terjadi bahwa setelah pemberian intervensi self management program mengakibatkan pasien meyakini segi positif dan negatif dari perilaku sehat berdasarkan self-management program sehingga terbentuk sikap dan reaksi suka dengan metode self-management program untuk pengelolaan PJK di rumah (behavioral belief), karena mereka menilai bahwa metode ini sangat bermanfaat (outcome evaluation). Keluarga juga mendampingi dan mendukung metode pengelolaan penyakit PJK berdasarkan selfmanagement program. Hal ini dapat mempengaruhi pasien untuk menerima informasi yang diberikan oleh pemberi intervensi (normative belief) sehingga dimungkinkan meningkatkan motivasi pasien untuk mematuhi cara pengelolaan PJK berdasarkan self-management program (motivation to comply). Pasien yang mengalami peningkatan koping merupakan individu yang mempercayai pengobatan secara medis (controllability) mengakibatkan ada persepsi pasien bahwa mereka mampu untuk melaksanakan pengelolaan PJK di rumah seumur hidup (perceived belief). Dengan demikian, selfmanagement dapat mempengaruhi perilaku seseorang dalam berobat (Ajzen, I., 2009). Sehingga pasien dengan PJK yang telah mendapat intervensi self-management lebih memiliki intens atau niat berobat lebih tinggi.

Dari semua uraian jurnal dan text book di atas, didapatkan kesimpulan bahwa semua penerapan self-management dan dukungan keluarga di setiap elemen dan penyakit kronis memiliki dampak positif yang baik terhadap pasien dengan penyakit kronis dalam me-manage dirinya, sehingga klien dapat mengontrol pikiran dan perilaku terhadap kesehatannya. Penelitian-penelitian tersebut di atas membuktikan bahwa dengan dukungan keluarga yang baik dapat meningkatkan self-management yang baik pula bagi klien dengan penyakit kronis.

Self-management yang harus dilakukan oleh pasien dengan penyakit kronis yaitu pertama dimulai dari niat pasien itu sendiri. Yang kedua yaitu pasien memahami kondisi 
penyakit dan dirinya, yang ketiga yaitu pasien bisa mengatur pola hidup sehat baik dari segi makanan, aktifitas dan juga lingkungannya, dan yang keempat yaitu pasien bisa memanfaatkan fasilitas kesehatan yang ada untuk rutin memeriksakan kesehatannya.

\section{KESIMPULAN}

Berdasarkan hasil penelitian dari ketujuh artikel dan 1 text book didapatkan kesimpulan bahwa terdapat pengaruh yang positif self-management dan dukungan keluarga terhadap penanganan pada lanjut usia dengan penyakit-penyakit kronis. Keduanya pun saling berhubungan, klien dengan penyakit kronis dapat percaya dan menggunakan self-management nya dengan baik ketika mendapat dukungan dari keluarga yang baik pula.

\section{REFERENSI}

1. Al-Qur'an dan Terjemahnya. Kementrian Agama RI, 2014.

2. Ajzen, I. 2009. Organizational Behavior and Human Decision Processes. The Theory Of Planned Behavior. Diakses pada tanggal 11 Agustus 2018.

3. Allender, J.A., Rector, C., \& Warner, K.D. 2010. Community Health Nursing: Promoting and Protecting The Public's Health. Philadelphia: Lippincott Williams \& Wilkins.

4. Angelina, Pretty. 2016. Hubungan SelfManagement Dengan Kualitas Hidup Pasien Pasca Stroke Di Wilayah Puskesmas Pisangan Ciputat. Skripsi. UIN Syarif Hidayatullah. Jakarta

5. Avendano M, Glymour MM, Banks J, Mackenbach JP. Health disadvantage in US adults aged 50 to 74 years: A comparison of the health of rich and poor Americans with that of Europeans. American Journal of Public Health 2009.
6. Booger, Emma Joanne. 2014. SelfManagement Following Stroke: Concept and Measurement. Disertasi Program Doktor Filosofi Universitas Southampton.

7. Centers for Disease Control and Prevention (CDC). 2008. National Center for Health Statistics. Health, United States. http://www.cdc.gov/nchs/datawh/nchsdef s/healthconfition.htm\#chronic. Diakses pada Sabtu, 11 Agustus 2018.

8. Christensen, P.J. \& Janet, W. Kenney. 2009. Proses Keperawatan Aplikasi Model Konseptual. Edisi 4. Jakarta: EGC.

9. Damayanti, S., dkk. 2015. Dukungan Keluarga pada Pasien Diabetes Melitus Tipe 2 dalam Menjalankan SelfManagement Diabetes. Skripsi: Universitas Padjadjaran Bandung.

10. Denham, S.A., \& Looman, W. 2010. Families With Chronic Illness, family Health Care Nursing, Theory, Practice and Research. Davis Company: Philadelphia.

11. De Silva, D. Helping People Help Themselves. A Review of The Evidence Considering Whether It Is Worthwhile To Support Self-Management (ISBN: 978-1-906461-26-3). London, UK: The Health Foundation.

12. Fadhil, ZA. 2012. Kultum 16-Kajian Surat At-Taubah. http://www.fadhilza.com/2012/12/kum pulan-kultum/kultum-16-kajian-suratat-taubah-ayat-51.html. Diakses pada tanggal 16 Agustus 2018.

13. Riedman, Marilyn M. 2010. Buku Ajar Keperawatan Keluarga: Riset, Teori dan Praktek. Jakarga: EGC.

14. Galuh, Lestari, I., \& Isnaini, Nur. 2018. Pengaruh Self-Management Terhadap Tekanan Darah Lansia Yang Mengalami Hipertensi. Indonesian Journal for Health Sciences, Vol.2, No.01. 
15. Gomes, C., Boas, V., \& Foss, M. 2012. Relationship Among Sosial Support, Treatment Adherence and Metabolic Control Of DM Patient. [Thesis] [PubMed].

16. Hannah, L. Parke, dkk. 2015. SelfManagement Support Interventions For Stoke Survivors: A Systematic MetaReview. Research Article.

17. Huana, C. dkk. 2015. Strategies For Self-Management Support By Patients With Stroke: Integrative Review. Journal Of School Nursing.

18. Isra, M. dkk. 2017. Hubungan Dukungan Keluarga Dengan Derajat Hipetensi di Puskesmas Ranomuut Kota Manado. Skripsi: Universitas Sam Ratulangi Manado.

19. Jhonson \& Leny. 2010. Keperawatan Keluarga. Yogyakarta: Nuha Medika.

20. Johnston, S., dkk., 2010. Chronic Disease Self-Management. The Champlain Local Health Integration Network. A Literature Review.

21. Kane, R.L., Ouslander, J.G., Abras, L.B. 2008. Essential of Clinical Geriatrics $\left(3^{\text {rd }} E d\right)$. New York: McGraw Hill.

22. Kennedy, KM., Raz, N. 2010. Aging White Matter and Cognition: Differential Effects of Regional Variations in Diffusion Properties On Memory, Executive Function, and Speed. Neuropsychologia. [PMC free article] [PubMed].

23. Kisokanth, G., Prathapan, S., Indrakumar, J. \& Joseph, J. 2013. Factors Influencing Self-Management of Diabetes Mellitus; A Review Article. Journal of Diabetology.

24. Kitts, Jack. 2013. Self-Management Support For Canadians With Chronic Health Conditions: A Focus For Primary Health Care. Health Council of Canada.

25. Kuntjoro, Z. S. 2008. Jurnal Psikologi: Dukungan Sosial Pada Lansia. http://www.e.psikologi.com/usia/16080 2.htm. Diakses pada tanggal 11 Agustus 2018.

26. Lennon, Sheila, et al. 2013. SelfManagement Programmes For People Post Stroke: A Systematic Review. Article of Clinical Rehabilitation.

27. Lestari, Inda G. \& Isnaini, Nur. 2018. Pengaruh Self-Management Terhadap Tekanan Darah Lansia Yang Mengalami Hipertensi. Indonesian Journal Health Science.

28. Lorig KR., dkk., 2008. Chronic Disease Self-Management Program. Med Care.

29. Isabel, M., dkk. 2015. SelfManagement and Family Support In Chronic Diseases. Journal of Nursing Education and Practice. Vol.5. No.11.

30. Maryam, dkk. 2008. Mengenal Usia Lanjut dan Perawatannya. Jakarta: Salemba Medika.

31. McGowan, P. 2011. The Efficacy of Diabetes Patient Education and SelfManagement Education in type 2 diabetes. Canadian Journal of Diabetes.

32. Mufarokhah, H., dkk. Self Management Program Meningkatkan Koping, Niat, dan Kepatuhan Berobat Pasien PJK. Skripsi: Universitas Airlangga.

33. Ningrum. 2012. Hubungan Dukungan Keluarga Dengan Perilaku Makan Pada Pasien Hipertensi di Wilayah Kerja Puskesmas Minggir Sleman, Yogyakarta. (Diakses pada tanggal 11 Agustus 2018).

34. Nugroho, Wahjudi. 2009. Komunikasi dalam Keperawatan Gerontik. Jakarta: EGC.

35. Richard, A. A., \& She, K. 2011. Delineation of Self Care and Associated Concepts. J Nurs Scholarsh. 43(3).

36. Rosland, Ann-Marie. 2009. Sharing The Care: The Role of Family Care in 
Chronic Illness. California Healthcare Foundation.

37. Ryan. P., Sawin KJ. 2009. The Individual and Family SelfManagement Theory: Background and Perspectives On Context, Process, and Outcomes. Ners Outlook.

38. Sarafino, E. P. 2008. Health Psychology: Biopsychosocial Interactions. Fifth Edition. USA: John Wiley \& Sons.

39. Setiadi. 2008. Konsep \& Proses Keperawatan Keluarga. Jakarta: EGC.

40. Smeltzer, S. \& Bare, B. 2013. Buku Ajar Keperawatan Medikal Bedah Brunner \& Suddarth's, Edisi 8, Volume 1. Jakarta: EGC.
41. Sudiharto. 2008. Asuhan Keperawatan Keluarga dengan Pendekatan Transkultural. Jakarta: EGC.

42. Susilo, Y. \& Wulandari, A. 2011. Cara Jitu Mengatasi Hipertensi. Yogyakarta: Andi.

43. Thompson J. 2009. How Chronic Illness Affects Family Relationship and The Individual [Thesis]. Wisconsin: University of Wisconsin-Stout.

44. Turana Y, Mayza M, Pudjiastuti. 2013. Panduan Program Simulasi Otak pada Lansia. Jakarta: Nida Dwi Karya.

45. World Health Organization. 2014. Global Status Report On Noncommunicable Disease. http://www.who.int/nmh/publications/n cd-status-report-2014/en/. Accessed 11 August 2018. 